\title{
POSTSCRIPT
}

\section{BEING IN ONE'S PLACE: \\ RACE, ONTOLOGY AND THE KILLING OF TRAYVON MARTIN1}

\author{
Ron Scapp \\ College of Mount Saint Vincent \\ Immediate Past-President of the National Association \\ for Ethnic Studies
}

The killing of Trayvon Martin along with the trial and acquittal of George Zimmerman provoked many discussions and debates: some touching upon painful issues, others just rather painful to listen to or read. What struck me most however were the conversations and opinions about what the killing, trial, and subsequent acquittal meant for our nation. What we came to learn is that the killing, trial and acquittal mean different things to different people. That fact should neither surprise us nor make us hesitant to examine, still further, the complex nature of the Trayvon Martin killing, its aftermath, and the history of our nation.

What I would like to suggest is that at the very core of this tragedy is the fundamental issue of what it actually means for an African American (especially a Black male) "to be" in the United States. I would argue that there is, and always has been, an ontological problem here: that there is, in fact, no proper or legitimate place for a person of color to be. This problem has been raised many times by different people, including the novelist and philosopher Charles Johnson in his Being and Race and by the writer and cultural critic bell hooks [sic] in her Black Looks, among other notable Americans.

I am specifically saying it is an ontological problem, in large part, due to the very historical status of "being black" in the United States. Sadly, no matter where Trayvon Martin may have found himself, for too many Americans (including some people of color themselves), he would, by definition, be out of place. Thus, the suspicion George Zimmerman had, and acted upon, was a suspicion regarding the very existence of Trayvon Martin because as Angela Davis asserts, "[i]n our society, the assumption is that if you are from a certain racialized community, you

1 This commentary was originally published in the NAES FORum Pamphlet Series in 2013 (Volume 1, Article 1). It has been slightly modified for publication here. 
will have had some contact with the prison system [either directly or not]." And as a result "black men are essentially born with the social stigma equivalent to a felony conviction." George Zimmerman's "suspicion," therefore, of Trayvon Martin, and perhaps of anyone of color, would always render them "out of place," and hence worthy of observing, monitoring and policing.

Some may feel that this ontological assessment and predicament are an exaggeration of the current state of "being black" in the United States. But I would argue that it does not take much for us to uncover that very fundamental and presumed suspicion of a person of color's legitimacy, of his or her appropriateness to be anywhere. Take, for example, the sustained suspicion regarding the issue of Barak Obama's status as a real citizen throughout the duration of his presidency by many "concerned" Americans, including Donald J. Trump — the legitimacy of his birth is still doubted by any number of nervous and suspicious people, although apparently it is no longer the salient talking point for President Trump as it was for candidate Trump. This is not just some arbitrary suspicion about Obama's place (which for eight years was the White House); it is an historical reaction to a black man not being in his proper place, namely where White America can tolerate him. And here is the crux of the matter: due to the very complex history of our nation's birth and development, it is hard, if not impossible, for a person of color to be ever in the right place-in large measure because every place is a charged and a vexed reminder of how Africans came to be here in the first place. This material history haunts our nation like some racist specter, spooking and frightening too many citizens about the legitimacy of too many other citizens - a curse, as it were, that our nation lives with every day, despite the efforts to either justify the suspicion or to outright deny its existence.

There is much more to discuss (including, for example, the very "stand your ground law" that was essential to Zimmerman's defense). But, no matter what else the killing of Trayvon Martin means to contemporary Americans, it must remind us all (White, Black, Latino, Asian American, Native American, male, female, gay, straight, transgender) that being in the world, specifically being in the United States is a complex, and still a very dangerous, and at times a very deadly, place to be. "Being" here in the United States has a history, unfortunately a very violent and bloody one. And we who now inhabit this diverse nation need to remain ever vigilant and determined to overcome our many suspicions, but especially the suspicion that automatically makes us assume that Trayvon Martin and the many others killed since him were in the wrong place, and could never actually be in the right place.

Finding one's place in the world is hard enough, but it becomes an almost impossible journey of self-discovery if we systematically make 
being in one's place a mandate to stay in someplace that only those deemed free of suspicion get to determine as appropriate for others (of dubious status). The killing of Trayvon Martin, the suspicion George Zimmerman had of him that led up to the killing, and the many similar manifestations of that suspicion that have followed, remind us that traversing the contours of our nation, and even the streets of our own neighborhoods, has never been free from risk, never free from both historical and ideological misrepresentations. The killing of Trayvon Martin, those killed before him, those killed even before the birth of our nation, and those killed since (in just about every conceivable circumstance) are sad and real reminders that we as a nation have a long way to go, as both Walt Whitman and Malcolm X would put it, "to become what we someday will be." 